\title{
Sexual state of grape powdery mildew (Erysiphe necator) newly recorded for New Zealand
}

\author{
P.R. Johnston ${ }^{1}$, J.A. Cooper ${ }^{1}$, D. Park 1 , P.W. Sutherland ${ }^{2}$ and P.N. Wood ${ }^{2}$ \\ ${ }^{1}$ Landcare Research, Private Bag 92170, Auckland 1142, New Zealand \\ ${ }^{2}$ Plant E Food Research, Private Bag 1401, Havelock North, Hastings 4157, New Zealand \\ Corresponding author: JohnstonP@landcareresearch.co.nz
}

Grape powdery mildew, first reported in New Zealand in 1901, is widespread in New Zealand grape growing regions, causing significant losses in some seasons. In the summer of 2014, the sexual stage of this fungus was observed for the first time in New Zealand. Subsequent surveys showed the sexual state as widespread in Gisborne, Hawke's Bay and Marlborough. Internationally, two E. necator populations are recognised, Group A being asexual, while Group B undergoes sexual recombination. DNA was obtained from a sexual isolate from Hawke's Bay and from an asexual isolate from Canterbury and they matched Group B and Group A respectively. Asexual populations overwinter in dormant buds and develop new infections at budbreak, whereas sexual populations overwinter as cleistothecia (sexual fruiting bodies) with primary infections following ascospore release. In Europe, where both sexual and asexual populations are widespread, overwintering through cleistothecia is considered most important for between season transmission. The impact of this newly introduced powdery mildew population is as yet unknown but, with the additional source of new season inoculum coupled with greater genetic diversity increasing the risk of fungicide resistance, future control of the disease may become more difficult.

\section{Impact of Puccinia psidii on Māori taonga plant species}

\author{
T.T. Alipia ${ }^{1,2}$, D.A.J. Teulon ${ }^{1,2}$, M.G. Cromey ${ }^{1}$, A.T. Marsh ${ }^{3}$ and S.L.H. Viljanen-Rollinson ${ }^{1,2}$ \\ ${ }^{1}$ The New Zealand Institute for Plant \& Food Research Limited, Private Bag 4704, Christchurch 8140, New \\ Zealand \\ ${ }^{2}$ Better Border Biosecurity (www.b3nz.org), New Zealand \\ ${ }^{3}$ The New Zealand Institute for Plant \& Food Research Limited, Private Bag 11600, Palmerston North 4442, \\ New Zealand \\ Corresponding author: suvi.viljanen@plantandfood.co.nz
}

Myrtle rust, caused by the pathogen Puccinia psidii sensu lato, is a disease of species in the plant family Myrtaceae that is not found in New Zealand. It originates in South America, but it has steadily spread around the world and is now found in Australia and New Caledonia. While the potential economic and environmental impact of myrtle rust establishment in New Zealand has been well documented, the potential socio-cultural consequences, including those for Māori, have not. All New Zealand Myrtaceae species, including indigenous species, are at risk from $P$. psidii infection but the potential impact on their health is not known. All indigenous Myrtaceae species can be considered as Taonga (or treasure) by Māori, who have utilised the properties (e.g. spiritual, medicinal, construction, tools, food) of some species in many ways, both tangible and intangible. Optimally, preparedness and response plans for a myrtle rust incursion in New Zealand should consider the unique spiritual and other values that Māori associate with these plants. 